H. A. Malthuf Siroj

\title{
EKSISTENSI HUKUM ISLAM DAN PROSPEKNYA DI INDONESIA
}

\author{
Universitas Nurul Jadid Paiton Probolinggo \\ Email: malthuf@gmail.com
}

\begin{abstract}
Indonesia as one of the most populated-by-Muslim country has a long historical experience in implementing Islamic law. In each era, the practice of Islamic law differs one another due to the legal politics which influence it. Prior to the Dutch colonialism, Islamic law was prevalent among Muslims with political support from the royal kingdom of Islam such as in Aceh, Palembang, Banjarmasin, Banten, Demak, Jepara, Tuban, Gersik, Ampel and Mataram. Islamic law grew and developed in the midst of society beside adat law. In the Dutch colonial era the policy of the colonial government against Islamic law had its ups and downs in line with the legal theory that emerged at the time. On the one hand, it tends to be accommodative, while confrontational on the other hand. In the era of independence the position of Islamic law became stronger with the enactment of the 1945 Constitution which guaranteed the right of every citizen to embrace religion and practise religious law. In the New Order era, several laws have been enacted, which strengthened the position of Islamic law, especially the Islamic civil law. This tends to develop in the Reform era, marked by strengthening Muslim aspirations and regional autonomy. Consequently, the Islamic law is increasingly practised, though still limited in the field of civil law and Islamic economics. The enforcement of Islamic criminal law in Indonesia still encounter many obstacles both conceptually and legally. This article will examine the existence and the prospect of Islamic law in Indonesia by observing its strengths, weaknesses, opportunities and challenges.
\end{abstract}

Keywords: Existence, Prospect, Islamic Law, Strengths, Weaknesses, Opportunities, Challenges 
Abstrak: Indonesia sebagai negara yang penduduknya mayoritas beragama Islam mempunyai pengalaman sejarah yang panjang dalam pengamalan bukum Islam. Dalam setiap orde pemerintahan pengamalan bukum Islam berbeda satu sama lain karena perbedaan politik hukum yang dimainkannya. Sebelum penjajahan Belanda hukum Islam telah berlaku di kalangan umat Islam dengan dukungan politik dari kerajaaan kerajaan Islam seperti di Aceh, Palembang, Banjarmasin, Banten, Demak, Jepara, Tuban, Gersik, Ampel dan Mataram. Hukum Islam tumbuh dan berkembang di tengahtengah masyarakat di samping hukum Adat. Dalam era penjajahan Belanda politik hukum pemerintah kolonial terhadap hukum Islam mengalami pasang surut sejalan dengan teori bukum yang muncul pada saat itu. Di satu sisi bersikap akomodatif dan disisi lain konfrontatif. Dalam era kemerdekaan posisi hukum Islam semakin kuat dengan diberlakukannya UUD.45 yang menjamin hak setiap warga negara untuk memeluk agama dan mengamalkan bukum agama. Dalam masa Orde Baru telah diundangkan beberapa undang-undang yang memperkokoh posisi bukum Islam khususnya bukum perdata Islam, dan kondisi ini semakin berkembang pada era reformasi yang ditandai dengan penguatan aspirasi umat Islam dan otonomi daerah sehingga undang-undang yang bernuansa Islam semakin mengkristal sungguhpun masih terbatas dalam bidang bukum perdata dan ekonomi Islam. Pemberlakuan bukum pidana Islam di negara kita masib menghadapi banyak hambatan baike konseptual maupun politik bukum. Artikel ini akan mengkaji eksistensi dan masa depan bukum Islam di Indonesia dengan melihat kekuatan, kelemahan, peluang dan tantangannya.

Kata Kunci: Eksistensi, Prospek, Hukum Islam, Kekuatan, Kelemahan, Peluang, Tantangan

\section{Pendahuluan}

Term hukum Islam dalam bahasa Indonesia adalah sinonim dari term fiqh dalam bahasa Arab. Fiqh secara etimologis berarti memahami. Secara terminologis berarti studi tentang hukumhukum Allah mengenai perbuatan subyek hukum (mukallaf) yang digali dari Al-Qur'an dan Hadits dengan mengerahkan potensi akal (ijtihad) dengan metode tertentu. Jadi pengertian fiqh secara terminologis ini tidak terlepas sama sekali dari pengertian etimologisnya, karena fiqh pada prinsipnya dikembangkan melalui 
proses memahami oleh para ulama dalam menggali hukum dari sumber pokoknya yaitu Al-Qur'an dan Hadits.

Dalam kaitan ini terdapat term lain yang sering dihubunghubungkan dengan fiqh yaitu term syariah. Syari'ah ini mempunyai konotasi yang berbeda dari fiqh. Ia memiliki pengertian yang bersifat umum dan khusus. Syari'ah dalam pengertian umum adalah keseluruhan pranata kehidupan menurut Islam, termasuk didalamnya tentang akidah/kepercayaan terhadap Allah SWT. Syari'ah dalam pengertian ini sering disebut dengan fiqh akbar. Sedangkan syari'ah dalam pengertian khusus berkonotasi fiqh atau sering disebut dengan fiqh ashghar dengan pengertian sebagaimana tersebut di atas. Dari kata syari'ah selanjutnya terbentuk kata tasyri' Islamy yaitu peraturan perundang-undangan yang disusun berdasarkan Al-Qur'an dan Hadits sebagai sumber pokok ajaran Islam yang secara global substansinya dapat dibagi ke dalam dua kategori yaitu ibadat dan muamalat. Selain tasyri' Islamy terdapat term tasyri wadl'i yaitu peraturan perundang-undangan yang disusun berdasarkan pemikiran manusia secara murni tentang apa yang dianggap penting bagi kehidupannya.

Hukum Islam berkembang sejalan dengan perkembangan dan perluasan wilayah kekuasaan Islam serta persentuhannya dengan budaya dan bangsa-bangsa lain. Hukum Islam berkembang pesat pada saat Islam mengalami masa keemasannya pada zaman Dinasti Abbasiyah. Bersamaan dengan itu pula muncul tren-tren pemikiran (madzhab) hukum Islam yang memperkaya wacana hukum Islam dan mempercepat dinamikanya. Hukum Islam di wilayah kekuasaan Islam berlaku sebagai hukum positif yang berlaku bagi seluruh rakyat. Setiap negara Islam atau negara yang penduduknya mayoritas beragama Islam mempunyai pengalaman yang berbeda dalam penerapan hukum Islam termasuk Indonesia yang belakangan ini telah mencanangkan reformasi dalam segala aspek kehidupan termasuk aspek hukum. Dalam konteks ini sangat menarik untuk dikaji bagaimana eksistensi hukum Islam dan prospeknya di Indonesia berdampingan dengan hukum-hukum lain baik hukum adat maupun hukum yang berasal dari Barat. Dan Indonesia dalam hal ini mempunyai pengalaman tersendiri dalam perberlakuan hukum Islam yang berbeda dalam setiap orde pemerintahan karena perbedaan politik hukum yang dimainkannya. 


\section{Eksistensi Hukum Islam di Indonesia}

Sejarah perkembangan hukum Islam di Indonesia tidak dapat dipisahkan dari sejarah perkembangan Islam itu sendiri. Hukum Islam merupakan bagian yang penting, jika tidak disebut yang terpenting, dalam Islam. Hukum Islam adalah representasi pemikiran Islam, manifestasi yang paling khas dari pandangan hidup Islam dan intisari dari Islam itu sendiri.

Hukum Islam masuk di Indonesia bersamaan dengan masuknya agama Islam di negara ini. Terdapat tiga teori tentang masuknya Islam ke Nusantara, yaitu teori Gujarat (India), teori Mekkah (Arab), dan teori Persia. Ketiga teori ini mencoba memberikan jawaban tentang permasalahan masuknya Islam ke Nusantara berkenaan dengan waktu masuknya, asal negara yang menjadi perantara, atau sumber pengambilan ajaran Islam dan pelaku penyebarannya. ${ }^{2}$

Teori pertama ${ }^{3}$ mengatakan bahwa awal penyebaran Islam di Indonesia pada abad ke-13 M. Tempat asalnya Gujarat dan pelakunya adalah para pedagang India yang telah memeluk agama Islam. Teori kedua ${ }^{4}$ lebih cenderung mengatakan bahwa penyebarannya terjadi pada abad ke-7 M. Dalam teori ini terdapat dua pendapat tentang asal negara dari mana Islam masuk. Satu pendapat mengatakan, berasal dari Gujarat, dan yang lain mengatakan, berasal dari Timur Tengah, yaitu Mesir dan Mekkah, dan pelaku penyebarannya adalah pedagang Arab. Teori ketiga ${ }^{5}$ berpendapat bahwa Islam yang masuk ke Nusantara berasal dari Persia, singgah di Gujarat, dan terjadi pada abad ke-13.

Pemaparan teori-teori masuknya Islam ke Indonesia sebagaimana tersebut di atas tidak dimaksudkan untuk mengulang polemik tentang persoalan tersebut, tetapi sekadar ingin

1 Joseph Schacht, an Introduction to Islamic Law, terj. Joko Supomo, Islamika,Yogyakarta, 2003, 1

2 Ahmad Mansur Suryanegara, Menemukan Sejarah Wacana Pergerakan Islam di Indonesia, Mizan, Bandung, 1995, 74

${ }^{3}$ Peletak teori ini adalah Snouck Hurgronje. Lihat, ibid., 75

${ }^{4}$ Yang melahirkan teori ini adalah Hamka sebagai koreksi terhadap teori pertama. Disampaikan dalam pidatonya pada Dies Natalis PTAIN VIII di Yogyakarta pada tahun 1958. Lihat, ibid., 81

${ }^{5}$ Penggagas teori ini adalah PA Hoesein Djajadiningrat. Fokus pandangan teori ini lebih kepada tinjauannya terhadap kebudayaan yang hidup di kalangan umat Islam Indonesia yang mempunyai kemiripan dengan kebudayaan Persia, seperti peringatan 10 Muharram dan lain-lain. Lihat, ibid., 90 
menggambarkan bahwa hukum Islam yang merupakan bagian terpenting dari agama Islam telah lama dikenal oleh masyarakat Indonesia dan telah menjadi sebuah norma yang mengatur kehidupan mereka.

Pada masa kesultanan Islam, hukum Islam menjadi acuan penting dalam menyelesaikan kasus-kasus hukum yang timbul di tengah-tengah masyarakat. Karya Nuruddin Ar-Raniri yang hidup pada abad ke-17 di Aceh dengan judul Shirathul Mustaqim (Jalan Lurus) merupakan kitab hukum Islam yang pertama yang disebarkan ke seluruh Indonesia untuk menjadi acuan hukum umat Islam. Oleh Syekh Arsyad Banjar yang menjadi mufti di Banjarmasin, kitab ini diperluas dan diperpanjang uraiannya dan dijadikan acuan dalam menyelesaikan sengketa antarorang Islam di daerah kesultanan Banjar. Di daerah kesultanan Palembang dan Banten diterbitkan pula beberapa kitab hukum Islam sebagai acuan normatif dalam menyelesaikan kasus-kasus hukum yang terjadi. Hukum Islam juga diberlakukan di kerajaan-kerajaan Demak, Jepara, Tuban, Gersik, Ampel, dan Mataram. Dengan demikian, dapatlah dipahami bahwa sebelum Belanda mengukuhkan kekuasaannya di Indonesia, hukum Islam telah mempunyai kedudukan tersendiri dalam masyarakat. Sebagai hukum yang berdiri sendiri, hukum Islam telah ada dan berlaku di dalam kehidupan masyarakat Indonesia, tumbuh dan berkembang di samping hukum adat. ${ }^{6}$ Pada masa penjajahan Belanda, perkembangan hukum Islam di Indonesia dapat dilihat dalam dua bentuk. Pertama, adanya toleransi pihak Belanda melalui VOC yang memberikan ruang agak luas bagi perkembangan hukum Islam; bahkan dapat dikatakan bahwa VOC turut membantu menyusun suatu Compendium yang memuat hukum perkawinan dan hukum kewarisan Islam dan berlaku di kalangan umat Islam. Kedua, adanya upaya intervensi Belanda terhadap hukum Islam dengan menghadapkannya pada hukum adat. ${ }^{7}$

Pernyataan di atas menggambarkan pasang surut politik hukum Belanda terhadap hukum Islam sebagai pengaruh teori-teori yang muncul saat itu, seperti teori Receptie in Complexu. Teori ini digagas oleh Solomon Keyzer yang kemudian dikuatkan oleh Christian Van

${ }^{6}$ Muhamad Daud Ali, "Hukum Islam, Peradilan dan Masalahnya”, dalam Hukum Islam di Indonesia , Pemikiran dan Praktik, PT. Remaja Rosda Karya, Bandung,1991, 70

${ }^{7}$ Ratno Lukito, Pergumulan Antara Hukum Islam dan Hukum Adat di Indonesia, INIS, Jakarta, 1998), 28. 
den Berg (1845-1927). Menurut teori ini, hukum mengikuti agama yang dianut seseorang. Jika orang itu memeluk agama Islam, maka hukum Islam-lah yang berlaku baginya. ${ }^{8}$ Dalam bukunya Mubammadansch Recht, Van Den Berg menyatakan bahwa hukum Islam diperlukan bagi orang-orang Islam bumiputra walaupun dengan sedikit penyimpangan-penyimpangan. Teori inilah yang mempengaruhi sikap akomodatif VOC terhadap hukum Islam sehingga mereka tidak menganggapnya sebagai sebuah ancaman yang harus ditakuti. Dan berdasarkan teori ini pula Van den Berg mengusulkan agar dibentuk Pengadilan Agama di Indonesia. Usul ini direspons oleh pemerintah kolonial dengan dikeluarkannya Stbl.1882 No.152 yang diberlakukan di Jawa dan Madura. Hakim yang bekerja di Pengadilan Agama direkrut dari penghulu yang sekaligus menjadi penasihat Landraad dalam menyelesaikan suatu perkara. ${ }^{9}$

Sikap akomodatif seperti yang tersebut di atas tidak berlangsung lama karena pemerintah kolonial Belanda dipengaruhi oleh teori Receptie yang dikembangkan oleh Chrestian Snouck Hurgronje (1857-1936), yang selanjutnya disistemisasikan secara ilmiah oleh Van Vollen Hoven dan Ter Harr. Teori ini didasarkan kepada hasil penelitian yang dilakukan oleh Hurgronje di Aceh. Menurutnya, yang berlaku dan berpengaruh bagi orang Aceh yang mayoritas beragama Islam bukanlah hukum Islam. Dan hukum Islam baru memiliki kekuatan hukum apabila telah benar-benar diterima oleh hukum adat. Jadi, hukum adat-lah yang menentukan berlaku-tidak berlakunya hukum Islam. ${ }^{10}$ Sebagai akibat teori ini, maka perkembangan hukum Islam mengalami hambatan karena pemerintah kolonial Belanda mengeluarkan kebijakan baru yang membatasi kewenangan Pengadilan Agama dengan mengeluarkan Stbl. 1937 No. 116 dan 610. ${ }^{11}$ Teori Receptie ini cukup berpengaruh di Indonesia sampai kurun waktu tahun 1970. Tetapi, setelah Indonesia merdeka dan UUD 45 berlaku sebagai dasar negara, sekalipun tanpa memuat tujuh kata dalam Piagam Jakarta, maka

${ }^{8}$ Ichtijanto, "Pengembangan Teori Berlakunya Hukum Islam di Indonesia", dalam Tjun Suryaman (ed.), Hukum Islam di Indonesia: Perkembangan dan Pembentukan, Rosda Karya, Bandung, 1991, 123.

9 Abdul Manan, Reformasi Hukum Islam di Indonesia, PT.RajaGrafindo Persada, Jakarta,2006, 2.

${ }^{10}$ Muhamad Daud Ali, Hukum Islam, 72

${ }^{11}$ Abdul Mannan, Reformasi Hukum Islam, 2-3. 
teori Receptie di atas dinyatakan tidak berlaku lagi dan kehilangan dasar hukumnya. Selanjutnya, hukum Islam berlaku bagi bangsa Indonesia yang beragama Islam sesuai dengan ketentuan pasal 29 UUD 45.

Dalam hubungan ini, yang perlu dicatat dari perjuangan mempertahankan eksistensi hukum Islam pada masa pasca kemerdekaan adalah banyaknya teori yang bermunculan sebagai counter theory terhadap teori Receptie. Paling tidak, ada tiga teori yang mncul kemudian. Pertama, teori Receptie Exit yang dicetuskan oleh Hazairin. Teori ini menyatakan bahwa teori Receptie harus exit (keluar) dari teori hukum Islam Indonesia karena bertentangan dengan UUD 45, Al-Qur'an, dan Hadits. Kedua, teori Receptio a Contrario yang dikemukakan oleh Sayuti Thalib. Teori ini mengatakan bahwa hukum yang berlaku bagi rakyat Indonesia adalah hukum agamanya. Hukum adat hanya berlaku apabila tidak bertentangan dengan hukum agama. ${ }^{12}$ Ketiga, teori Eksistensi yang dikemukakan oleh Ichtijanto. Secara substansial teori ini sebenarnya hanya lebih mempertegas teori-teori yang muncul sebelumnya, yakni teori Receptie Exit dan teori Receptio a Contrario tentang hubungan dan posisi hukum Islam dalam sistem hukum nasional. Menurut teori Eksistensi, hukum Islam "telah ada" dalam sistem hukum nasional dan menjadi kenyataan yang tidak dapat dipungkiri keberadaannya dalam sistem hukum naasional ${ }^{13}$

Pengertian "telah ada" hukum Islam di atas adalah :

1. Hukum Islam merupakan bagian integral dari hukum nasional;

2. Dengan kemandirian dan kekuatan wibawanya, hukum Islam diakui oleh hukum nasional dan diberi status sebagai hukum nasional;

3. Norma hukum Islam berfungsi sebagai penyaring bahan bahan hukum nasional dan;

4. Hukum Islam sebagai bahan utama dan sumber utama hukum nasional. $^{14}$

${ }^{12}$ Amiur Nuruddin dkk.., Hukum Perdata Islam di Indonesia, Prenada Media, Jakarta,2004, 18.

${ }^{13}$ Ichtijanto, "Prospek Peradilan Agama Sebagai Peradilan Negara dalam Sistem Politik Hukum di Indonesia", dalam Amrullah Ahmad, Dimensi Hukum Islam dalam Sistem Hukum Nasional, Gema Insani Press, Jakarta,1996, 182-183.

${ }^{14}$ Mahsun Fuad, Hukum Islam Indonesia, LKiS, Yogyakarta,2005, 56. 
Teori-teori berlakunya hukum Islam di atas berpengaruh terhadap pemikiran politik hukum nasional yang memberikan ruang lebih terbuka bagi pemberlakuan hukum Islam sebagai hukum positif di Indonesia. Hal ini ditandai dengan diundangkannya Undang-Undang Nomor 14 Tahun 1970 tentang Ketentuan Ketentuan Pokok Kekuasaan Kehakiman. Pasal 10 ayat (1) dari Undang-Undang ini menyatakan bahwa badan peradilan dibagi ke dalam empat lingkungan, yaitu peradilan umum, peradilan agama, peradilan militer, dan peradilan tata usaha negara. ${ }^{15}$

Selanjutnya, hukum yang bernuansa Islam resmi menjadi hukum positif (lex positiva/ius constitutum) sejak diundangkannya Undang-Undang Nomor 1 Tahun 1974 tentang Perkawinan, yang kemudian dijabarkan dengan Peraturan Pemerintah Nomor 9 Tahun 1975. Undang-Undang ini berlaku bagi seluruh rakyat Indonesia dari berbagai agama tetapi nuansa keislamannya sangat kental, sehingga tidak heran apabila dalam proses legislasinya terjadi pergumulan politik yang ditandai tarik-menarik antara kelompok yang pro dan yang kontra terhadap rumusan pasal-pasal yang dinilai krusial dan kontroversial sebagai pengaruh dari semangat deislamisasi hukum Islam di satu sisi, dan formalisasinya di sisi yang lain

Dalam perkembangan berikutnya, diundangkanlah UndangUndang Nomor 7 Tahun 1989 tentang Peradilan Agama. ${ }^{16}$ Sebenarnya, usaha untuk memantapkan kedudukan Peradilan Agama sudah lama dirintis oleh Departemen Agama (sekarang disebut Kementerian Agama). Kegiatan penyusunan Rancangan Undang-Undang tentang Peradilan Agama sudah dimulai sejak tahun 1961, namun secara konkret baru terlaksana pada tahun 1971 berdasarkan Instruksi Presiden Nomor 15 Tahun 1970 Tentang Tata Cara Mempersiapkan Rancangan Undang-Undang dan

15 Undang-Undang Nomor 14 Tahun 1970 selanjutnya diubah dengan UndangUndang Nomor 35 Tahun 1999 tentang Perubahan atas Undang-Undang Nomor 14 Taun 1970 tentang Ketentuan Ketentuan Pokok Kekuasaan Kehakiman. Kemudian UndangUndang ini diubah kembali dengan Undang-Undang Nomor 4 Tahun 2004 tentang Kekuasaan Kehakiman dan diubah lagi dengan Undang-Undang Nomor 48 Tahun 2009 tentang Kekuasaan Kehakiman.

16 Undang-Undang. Nomor.7 Tahun 1989 selanjutnya diubah dengan UndangUndang.Nomor.3 Tahun 2006 tentang Perubahan atas Undang-Undang.Nomor 7 Tahun 1989 tentang Peradilan Agama dan diubah lagi dengan Undang-Undang Nomor 50 Tahun 2009 tentang Peradilan Agama. 
Rancangan Peraturan Pemerintah. Setelah melalui pembahasan yang cukup lama, Undang-Undang tentang Peradilan Agama tersebut baru dapat diundangkan pada tanggal 29 Desember 1989.

Di antara pokok pikiran yang terdapat dalam pertimbangan diundangkannya Undang-Undang Nomor 7 Tahun 1989 adalah untuk menyeragamkan kompetensi atau kewenangan Pengadilan Agama antara Jawa-Madura dan luar Jawa-Madura. Dengan berlakunya Undang-Undang ini, maka kompetensi absolut Pengadilan Agama di seluruh Indonesia menjadi sama dalam kerangka sistem dan tata hukum nasional, berdasarkan Pancasila dan UUD 45. Kompetensi atau kewenangan Pengadilan Agama dinyatakan dalam pasal 49 ayat (1) Undang-Undang Nomor 7 Tahun 1989: Pengadilan Agama bertugas dan berwenang memeriksa, memutus, dan menyelesaikan perkara perkara di tingkat pertama antara orang-orang yang beragama Islam di bidang a). perkawinan b). kewarisan, wasiat dan hibah yang dilakukan berdasarkan hukum Islam. c). wakaf dan shadaqah. Selanjutnya, ayat (2) dari UU tersebut di atas menyebutkan: Bidang perkawinan sebagaimana yang dimaksud dalam ayat (1) huruf a ialah hal-hal yang diatur dalam atau berdasarkan undang-undang mengenai perkawinan yang berlaku. Bidang kewarisan sebagaimana yang dimaksud dalam ayat (1) huruf b ialah penentuan siapa-siapa yang menjadi ahli waris, penentuan mengenai harta peninggalan, penentuan bagian masing-masing ahli waris dan melaksanakan pembagian harta peninggalan tersebut.

Agar dapat melaksanakan kewenangan yurisdiksi di atas, Pengadilan Agama memerlukan perangkat hukum material berupa hukum tertulis yang menjamin keseragaman putusan hukum. Secara materiil, memang telah ditetapkan 13 macam kitab untuk dijadikan rujukan dalam memutus perkara yang semuanya bermazhab Syafi'i, berdasarkan Surat Edaran Biro Peradilan Agama Nomor B/1/735 tanggal 18 Februari 1958 yang merupakan tindak lanjut Peraturan Pemerintah Nomor 45 Tahun 1957 tentang Pembentukan Pengadilan Agama/Mahkamah Syar'iyah di luar Jawa dan Madura. ${ }^{17}$

${ }^{17}$ Kitab-kitab tersebut adalah: Al-Bajuri, Fath al Mu'in, Syarqowi 'ala al-Tahrir, Qalyubi/Mahalli, Fath al-Wahhab dengan Syarah-nya, Tuhfah, Targhib al-Musytaq, Qawanin Syariyah li al-Sayyid Utsman ibn Yahya, Qawanin Syar'iyah li al-Sayyid Shadaqah Dahlan, Syamsuri fi al-Faraidl, Bughyah al- Mustarsyidin, al-Fiqh Ala al 
Tetapi, penetapan kitab standar tersebut belum dapat menjamin keseragaman putusan hukum, karena kitab-kitab tersebut masih mengandung bermacam pendapat para ahli hukum Islam, sungguh pun dari kalangan Syafi'iyah sendiri. Dalam kaitan ini, Munawir Syadzali mengatakan bahwa ada keanehan di Indonesia berkenaan dengan implementasi hukum Islam. Peradilan Agama sudah berusia sangat lama, namun hakimnya tidak memiliki buku standar yang dapat dijadikan rujukan yang sama seperti KUHP. Ini berakibat, jika para hakim agama menghadapi kasus yang harus diadili, maka rujukannya adalah berbagai kitab fiqh tanpa suatu standarisasi atau keseragaman. Akibat lanjutannya, praktis dalam kasus yang sama dapat lahir keputusan yang berbeda jika ditangani hakim yang berbeda. $^{18}$

Bertitik tolak dari realitas ini, keinginan untuk menyusun Kitab Hukum Islam dalam bentuk kompilasi dirasakan semakin mendesak. Ide penyusunan Kompilasi Hukum Islam timbul setelah berjalan dua setengah tahun Mahkamah Agung (MA) membina bidang teknis yustisial peradilan agama. Tugas pembinaan ini berdasarkan UU. No 14 Tahun 1970 yang menentukan bahwa pengaturan personil, keuangan, dan organisasi pengadilan pengadilan yang ada diserahkan kepada departemen masing-masing, sedangkan pengaturan teknis yustisial ditangani oleh Mahkamah Agung. Meskipun Undang-Undang tersebut telah ditetapkan pada tahun 1970, pelaksanaannya di lingkungan peradilan agama baru dapat dilakukan pada tahun 1983 setelah penandatanganan Surat Keputusan Bersama (SKB) oleh Ketua Mahkamah Agung dan Menteri Agama. SKB tersebut merupakan jalan pintas untuk tidak menunggu lahirnya ketentuan pelaksanaan Undang-Undang No 14 tahun 1970 bagi peradilan agama. Selama perjalanan dua setengah tahun itu, Mahkamah Agung menemukan beberapa hal yang perlu dibenahi. Di antaranya berhubungan dengan hukum yang diterapkan di lingkungan peradilan agama, yakni hukum Islam. Ada beberapa hal yang masih menjadi masalah:

Madzahib al-Arba'ah, Mughni al-Muhtaj. Lihat Kompilasi Hukum Islamdi Indonesia, Pengadilan Tinggi Agama Jawa Timur, 1995, 130.

${ }^{18}$ Lihat Munawir Syadzali, "Peradilan Agama dan Kompilasi Hukum Islam", dalam Dadan Muttaqin (ed.), Peradilan Agama dan Kompilasi Hukum Islam dalam Tata Hukum Indonesia, UII Press, Yogyakarta,1999, 2. 
1. Hukum Islam (figh) tersebar dalam sejumlah kitab karya para ahli fiqh (fuqaba) beberapa abad yang lalu. Hampir dapat dipastikan bahwa dalam setiap masalah selalu ditemukan lebih dari satu pendapat (qaul). Adalah wajar apabila seseorang bertanya hukum Islam yang mana? Bagi pribadi ataupun kelompok tertentu, mungkin hal itu tidak perlu dipertanyakan karena telah jelas, mengingat masing-masing telah menganut paham tertentu. Ini adalah kenyataan tanpa mengingkari bahwa terjadinya perbedaan pendapat adalah rahmat bagi umat. Tetapi yang ditekankan di sini adalah bahwa untuk dapat diberlakukan di pengadilan, suatu peraturan, termasuk hukum Islam, harus jelas dan sama bagi semua orang. Dengan kata lain, harus ada kepastian hukum.

2. Bahwa dasar keputusan Pengadilan Agama adalah kitab-kitab fiqh. Hal ini membuka peluang bagi terjadinya pembangkangan, atau setidaknya keluhan, ketika pihak yang kalah perkara mempertanyakan penggunaan kitab/pendapat yang tidak menguntungkan baginya dengan menunjuk kitab/pendapat lain yang menawarkan penyelesaian yang berbeda. Bahkan di antara 13 kitab standar itu, ada yang telah jarang dipergunakan sebagai rujukan dan sering pula terjadi para hakim berselisih sesama mereka tentang pemilihan kitab rujukan tersebut. Hal demikian tidak terjadi di Pengadilan Umum, sebab setiap keputusan Pengadilan selalu dinyatakan sebagai pendapat Pengadilan, sekalipun mungkin seorang hakim setuju dengan pendapat pengarang sebuah buku yang mungkin pula mempengaruhi putusan yang dijatuhkannya.

3. Hal lain adalah bahwa figh yang digunakan zaman sekarang dibentuk jauh sebelum lahirnya paham kebangsaan. Ketika itu praktik ketatanegaraan Islam masih memakai konsep umat. Berbeda dengan paham kebangsaan, konsep umat menyatukan berbagai kelompok dalam masyarakat dengan tali agama. Paham kebangsaan baru lahir sesudah Perang Dunia I dan negaranegara Islam pun menganutnya, termasuk negara-negara di dunia Arab. Dengan demikian, sejumlah produk dan peristilahan yang dihasilkan sebelum lahirnya paham kebangsaan tidak bisa digunakan lagi karena perbedaan konteks.

Kondisi hukum Islam sebagaimana digambarkan di atas inilah yang kemudian mendorong Mahkamah Agung menggagas 
pembentukan Kompilasi Hukum Islam. ${ }^{19}$ Maka dibentuklah Tim Pelaksana Proyek dengan Surat Keputusan Bersama (SKB) Ketua Mahkamah Agung dan Menteri Agama No 07/KMA/1985 dan No 25 Tahun 1985 Tanggal 25 Maret $1985 .{ }^{20}$ Dengan kerja keras seluruh anggota tim, para ulama, dan cendekiawan yang terlibat di dalamnya maka tersusunlah Kompilasi Hukum Islam (KHI) yang terdiri dari Buku I tentang perkawinan, Buku II tentang kewarisan, Buku III tentang perwakafan. Kemudian untuk memperoleh bentuk yuridisnya, Menteri Agama menyampaikan rumusan Kompilasi Hukum Islam tersebut kepada Presiden RI melalui surat tanggal 14 Maret 1988 Nomor MA/123/1988 Hal: Kompilasi Hukum Islam, dengan maksud memperoleh bentuk yuridis untuk digunakan dalam praktik di lingkungan Pengadilan Agama. Untuk itu, dikeluarkanlah Instruksi Presiden Nomor 01 Tahun 1991 Tanggal 10 Juni 1991 yang dalam diktumnya menyatakan: menginstruksikan kepada Menteri Agama untuk menyebarluaskan Kompilasi Hukum Islam yang terdiri dari Buku I tentang perkawinan, Buku II tentang kewarisan, dan Buku III tentang perwakafan sebagaimana telah diterima baik oleh para alim ulama Indonesia dalam lokakarya di Jakarta pada tanggal 25 Februari 1988 untuk digunakan oleh instansi pemerintahan dan oleh masyarakat yang memerlukannya. Dan untuk melaksanakan Instruksi Presiden tersebut, Menteri Agama mengeluarkan Surat Keputusan Nomor 154 Tahun 1991 Tanggal 22 Juni $1991 .{ }^{21}$

Dari beberapa pokok pikiran yang melatarbelakangi lahirnya Kompilasi Hukum Islam sebagaimana tersebut di atas, dapatlah dipahami bahwa perumusan Kompilasi Hukum Islam itu dimaksudkan sebagai upaya pembaruan hukum Islam di Indonesia demi terwujudnya kepastian hukum Islam dan agar hukum Islam itu relevan dengan perkembangan zaman dalam konteks keindonesiaan, karena kitab-kitab fiqh yang disusun para ahli hukum Islam beberapa abad lalu yang menjadi rujukan para hakim di Pengadilan Agama diyakini tidak dapat menjamin terwujudnya dua hal di atas, sebab, sebagaimana telah disebutkan, kitab-kitab Fiqh itu berbentuk uraian-uraian yang mengandung pendapat

\footnotetext{
19 Bustanul Arifin, Gagasan dan Sasaran Kompilasi Hukum Islam. Makalah, PTA Jawa Timur, 1995, 3-5.

${ }^{20}$ Kompilasi Hukum Islam di Indonesia, 137

${ }^{21}$ Ibid., 152-153.
} 
pendapat para ahli hukum Islam dengan segala perbedaannya, dan pada umumnya kitab-kitab tersebut disusun pada zaman di mana hukum Islam sedang mengalami stagnasi karena lemahnya semangat ijtihad di kalangan umat Islam. Begitu juga, ilmu pengetahuan yang berpengaruh besar terhadap kehidupan masyarakat masa itu belum semaju sekarang, sehingga relevansi kitab-kitab fiqh tersebut dengan kehidupan kontemporer masih perlu dipertanyakan.

Dalam perkembangan berikutnya, sejalan dengan tuntutan reformasi dan otonomi daerah, politik hukum yang dimainkan pemerintah Orde Reformasi semakin membuka peluang bagi legislasi hukum Islam baik di tingkat nasional maupun daerah yang tentu akan semakin memperkuat eksistensi hukum Islam di Indonesia. Dengan demikian hukum Islam di samping eksis sebagai ketentuan perundang-undangan juga eksis dalam bentuk norma yang mengatur prilaku umat Islam Indonesia dalam kehidupan sehari-hari baik individual maupun sosial sekaligus sebagai bentuk pengamalan ajaran agama Islam yang diyakini kebenarannya.

\section{Hukum Islam dalam Sistem Hukum Nasional}

Indonesia adalah sebuah negara kepulauan yang penduduknya sangat plural dari segi etnik, budaya, dan agama. Mayoritas penduduknya beragama Islam. Indonesia pernah dijajah oleh Belanda selama kurang lebih 350 tahun, masa yang cukup lama. Di samping itu Indonesia juga pernah dijajah oleh Spanyol, Portugis, Inggris, dan Jepang dalam waktu yang tidak terlalu lama dibandingkan dengan masa penjajahan Belanda. Dilihat dari pluralitas penduduk dan pengalaman sejarahnya sebagai negara jajahan, maka amat wajar apabila di Indonesia juga terdapat pluralitas sistem hukum. Di negara kita terdapat tiga sistem hukum, yaitu hukum adat, hukum Islam, dan hukum Barat. Penyebutan secara berturut-turut ini adalah berdasarkan usia masa berlakunya di Indonesia. Hukum adat merupakan hukum yang usianya paling tua di negara kita dibandingkan hukum-hukum yang lain. Sejak tahun 1927, hukum adat mulai dipelajari dan diperhatikan secara saksama dalam rangka pelaksanaan politik hukum pemerintah Belanda setelah dikukuhkannya teori receptie dalam peraturan yang berlaku saat itu.

Hukum Islam baru dikenal di Indonesia sejak agama Islam disebarkan di negara ini. Sejalan dengan pesatnya penyebaran agama 
Islam maka hukum Islampun semakin dikenal dan mengakar dalam kehidupan umat Islam Indonesia. Sebagai hukum yang bersumber dari agama, hukum Islam akan mengalami problem politik ketika diformalisasikan pengamalannya dalam negara Indonesia yang sangat pluralistik ini, karena hukum Islam tidak dapat dilepaskan dari agama Islam itu sendiri. Dan apabila masuk dalam tataran ideologi negara maka akan timbul problem politik. Lebih- lebih agama Islam dengan ajarannya yang sangat komprehensif dapat dipahami sebagai agama dan negara/politik(al- Islam din wa daulah). Pengalaman sejarah menunjukkan bahwa tarik menarik kepentingan antar kelompok agama telah mencapai titik klimaksnya dalam perdebatan perumusan dasar dan konstitusi negara Republik Indonesia yang pada akhirnya bermuara kepada suatu kompromi politik untuk menjaga persatuan dan kesatuan bangsa Indonesia. ${ }^{22}$ Indonesia secara konstitusional bukanlah negara Islam tetapi bukan juga negara sekuler yang memandang agama sebagai persoalan pribadi dan sama sekali terlepas dari negara. Suatu jalan tengah telah dicapai bangsa Indonesia untuk mengatasi kemelut ideologis dari gagasan menegenai suatu negara yang ingin mengakui suatu agama tertentu dan bersikap positif dan akomodatif terhadap agama lain. ${ }^{23}$ Jalan tengah itu adalah penerimaan Pancasila sebagai dasar dan ideologi negara yang dapat mempertemukan agama dan kepercayaan yang pluralistik, suku dan bahasa yang pluralistik pula dalam suatu kebersamaan, yang menurut Yunan Nasution merupakan hidayah Tuhan kepada bangsa Indonesia ${ }^{24}$ Franz Magnis Suseno dalam kaitan ini menulis bahwa Pancasila begitu tinggi dan mutlak nilainya bagi kelestarian bangsa dan negara Indonesia karena merupakan wahana dimana pelbagai suku, golongan, agama, kelompok budaya dan ras dapat hidup dan bekerjasama dalam usaha membangun kehidupan bersama tanpa adanya alienasi dari identitas mereka sendiri. $^{25}$

\footnotetext{
${ }^{22}$ Ali Haidar, Nahdatul Ulama dan Islam di Indonesia, PT. Gramedia Pustaka Utama, Jakarta, 1994, 254.

${ }^{23}$ Ibid.

${ }^{24}$ Yunan Nasution, Islam dan Problema-problema Kemasyarakatan, Bulan Bintang, Jakarta, 1988, 193

${ }^{25}$ Franz Magnis Suseno, Kuasa dan Moral, Gramedia Pustaka Utama, Jakarta, 2000, 113
} 
Tentang relasi agama dan negara para teoretisi fiqh siyasi (politik Islam) merumuskan beberapa teori. Teori tersebut dapat dibedakan dalam tiga paradigma :

1. Paradigma integralistik, menyatakan bahwa agama dan negara itu menyatu (integral). Wilayah agama meliputi politik atau negara. Negara merupakan institusi politik dan keagamaan sekaligus, karenanya seorang kepala negara adalah pemegang kekuasaan politik dan agama sekaligus. Menurut paradigma ini pemerintahan diselenggarakan atas dasar kedaulatan Tuhan karena sesungguhnya kedaulatan itu berasal dari Tuhan itu sendiri.

2. Paradigma Sekularistik, paradigma ini menekankan pemisahan antara agama dan negara. Keduanya memiliki wilayah kerja masing masing yang tidak perlu saling mengintervensi. Agama adalah agama dan negara adalah negara.

3. Paradigma Mutual Simbiotik. Menurut paradigma ini relasi antara agama dan negara bersifat mutual simbiotik, artinya saling membutuhkan satu sama lain. Dalam hal ini agama membutuhkan negara, karena dengan kekuatan negara agama bisa berkembang. Demikian juga negara membutuhkan agama, karena dengan agama, negara dapat berkembang dengan bimbingan etika dan moral agama. ${ }^{26}$

Paradigma tentang relasi agama dan negara yang dianut di Indonesia adalah yang terakhir yaitu paradigma mutual simbiotik. Negara memiliki dasar negara Pancasila. Sila pertama adalah Ketuhanan yang Maha Esa. Sila ini menunjukkan bahwa agama di Indonesia mempunyai posisi strategis dan amat penting yang berarti bahwa seluruh warga negara Indonesia haruslah memeluk suatu agama tertentu dan dijamin kebebasannya dalam memilih dan mengamalkan ajaran agamanya.Kendatipun Indonesia bukan negara agama tapi posisi agama dalam kehidupan berbangsa dan bernegara menjadi acuan moral yang sangat fundamental, dan bahkan sila yang pertama dari Pancasila itu melandasi sila-sila yang lain yaitu Kemanusian yang Adil dan Beradab, Persatuan Indonesia, Kerakyatan yang Dipimpin oleh Hikmah Kebijaksanaan dalam Permusyawaratan Perwakilan dan Keadilan bagi Seluruh Rakyat Indonesia. Selanjutnya Pasal 29 ayat (2) UUD 45 tentang Agama

${ }^{26}$ Lihat Kamaruzzaman, Relasi Islam dan Negara, Indonesia Tera, Magelang,2001, 129 
menegaskan bahwa negara menjamin kemerdekaan tiap penduduk untuk memeluk agamanya masing-masing dan untuk beribadat menurut agamanya dan kepercayaan itu. Hukum Islam merupakan bagian yang penting dari agama Islam, karenanya pengamalan hukum Islam oleh orang Islam merupakan bentuk pengamalan ajaran agama sekaligus yang juga merupakan hak-hak rakyat yang harus memperoleh perlindungan dari negara sebagaimana ditegaskan dalam Pasal 28A sampai dengan Pasal 28J UUD 45.

Umat Islam di Indonesia secara kuantitatif adalah mayoritas yang berarti bahwa komposisi penduduk negara ini kebanyakan beragama Islam. Konsekuensi logis dari realitas sosial ini adalah bahwa aspirasi mayoritas penduduk Indonensia adalah menghendaki berlakunya hukum Islam dalam kehidupan mereka sebagai hukum yang bersumber dari agama yang kebenarannya tidak diragukan lagi, maka wajar apabila hukum Islam menjadi rujukan sebagai bahan hukum nasional yang sangat penting yang harus diacu dalam legislasi hukum nasional, karena menurut teori sosiological yurisprudence yang dikemukakan oleh Eugen Ehrlich bahwa hukum yang baik (ideal) itu adalah hukum yang dasar pembentukannya berasal dari dan sesuai dengan kenyataan hukum dalam masyarakat. ${ }^{27}$ Kenyataan hukum ini disebut dengan living law dan Just law yang merupakan kata kunci dalam teorinya. Suatu hukum dapat disebut sebagai living law(hukum yang hidup) dalam masyarakat apabila hukum itu berlaku secara yuridis, sosiologis dan filosofis. ${ }^{28}$

Sungguhpun hukum Islam telah menjadi hukum yang hidup (living law) dalam masyarakat Indonesia tetapi formalisasinya sebagai sebuah Undang-undang membutuhkan dukungan politik lebih lanjut. Sejak bergulirnya Orde Reformasi, konstelasi politik hukum pemerintah telah mengalami perubahan yang sangat signifikan dari sebelumnya di zaman Orde Baru yang cenderung mengebiri hakhak rakyat. Momentum baru itu memungkinkan aspirasi umat Islam yang menginginkan formalisasi hukum Islam dalam kehidupan berbangsa dan bernegara semakin mendapat ruang terbuka. Realitas ini tidak hanya terjadi di Indonesia dan dalam era kontemporer ini saja, tapi telah menjadi sebuah realitas di berbagai

${ }^{27}$ Lili Rasyidi \& Ira Rasyidi, Dasar dasar Filsafat dan Teori Hukum, PT Citra Aditya Bakti, Bandung, 2001, 66.

${ }^{28}$ Lihat Soerjono Soekanto\&Mustafa Abdullah, Sosiologi Hukum dalam Masyarakat, Rajawali, Jakarta, 1987, 13-14 
belahan dunia dan telah sejak lama terjadi. Dalam konteks ini, Muhammad Khalid Masud menyatakan bahwa tuntutan untuk menerapkan hukum Islam (syari'ah) sebagai hukum negara telah menjadi subjek perdebatan selama hampir dua abad. Intensitas perdebatan itu meningkat dalam abad kedua puluh selama proses pembentukan negara di dunia Islam. Lebih-lebih belakangan ini migrasi masyarakat muslim telah membawa perdebatan perdebatan ini ke benua Eropa, Amerika Utara dan Amerika Selatan. ${ }^{29}$

Politik hukum pemerintah Orde Reformasi terlihat lebih akomodatif terhadap aspirasi umat Islam, sejalan dengan semangat reformasi yang menuntut kebebasan dan jaminan hak-kak rakyat secara umum. Indikator yang meunjukkan bahwa politik hukum pemerintah lebih akomodatif adalah semakin banyaknya legislasi peraturan perundang-undangan yang bernuansa Islami dalam era reformasi,${ }^{30}$ misalnya diundangkannya Undang-Undang Nomor 17 Tahun 1999 tentang Penyelenggaraan Ibadah Haji, Undang-Undang Nomor 36 Tahun 1999 tentang Pengelolaan Zakat, UndangUndang Nomor 44 Tahun 1999 tentang Penyelenggaraan Keistimewaan Daerah Istimewa Aceh, Undang-Undang Nomor 41 Tahun 2004 tentang Wakaf, Undang-Undang Nomor 19 Tahun 2008 tentang Surat Berharga Syari'ah Negara, Undang-Undang Nomor 21 Tahun 2008 tentang Perbankan Syari'ah, Peraturan Mahkamah Agung RI Nomor 2 Tahun 2008 tentang Kompilasi Hukum Ekonomi Syari'ah dan lain-lain.

Pemberlakuan peraturan perundang-undangan yang bernuansa Islam di atas menunjukkan bahwa hukum Islam telah menjadi bagian integral dari hukum Nasional. Dengan kemandirian dan kekuatan wibawanya, hukum Islam diakui eksistensinya oleh sistem hukum Nasional dan diberi status sebagai hukum Nasional. Norma hukum Islam berfungsi sebagai penyaring bahan hukum Nasional bahkan hukum Islam diakui sebagai bahan utama dan sumber utama hukum Nasional. Dalam era reformasi sekarang ini eksistensi hukum Islam diakui memiliki kekuatan tersendiri yang

${ }^{29}$ Muhammad Khalid Masud, Pencarian Landasan Normatif Syariah Para Ahli Hukum Islam dalam Dinamika Kontemporer Dalam Masyarakat Islam, dihimpun oleh Dick van der Meij, terj. Soemardi,INIS, Jakarta, 2003, 3

${ }^{30}$ Produk legislasi adalah produk politik, hasil tarik menarik berbagai kepentingan politik yang mengejawantah dalam bentuk produk hukum. Lihat Moh.Mahfud MD, Politik Hukum di Indonesia, Cet.I, LP3ES, Jakarta, 1998, 2 
wujudnya bisa diaktualisasikan dalam bentuk legislasi, yurisprudensi dan kesadaran hukum masyarakat Indonesia (teori eksistensi komprehensiff.

Selain sistem hukum adat dan hukum Islam sebagaimana telah dijelaskan di atas, di Indonesia juga berlaku hukum Barat. Indonesia sebagai negara jajahan Belanda dalam kurun waktu yang cukup lama wajar apabila sistem hukumnya juga dipengaruhi oleh sistem hukum Belanda (civil law). Hingga sekarang, masih banyak hukum Belanda yang berlaku di Indonesia. Upaya untuk mewujudkan hukum nasional yang meng-Indonesia sampai sekarang masih sangat minim hasilnya, dan masih lebih sebagai sebuah retorika politik. Ini berarti bahwa bangsa Indonesia yang sudah merdeka lebih setengah abad belum mampu membangun jati dirinya dari aspek hukum. Hal ini menjadi tugas berat para ahli hukum kita untuk dapat mereformasi hukum-hukum peninggalan penjajah yang tidak sesuai dengan nilainilai dan karakter serta budaya bangsa Indonesia.

Ketiga sistem hukum tersebut di atas yaitu sistem hukum adat, sistem hukum Islam dan sistem hukum Barat sejak awal keberadaannya di Indonesia saling bersaing satu sama lain dalam mempertahankan eksistensinya di negara kita dan momentum akhir dari persaingan itu sangat ditentukan oleh kepentingan politik hukum pemerintah yang sedang berkuasa yang tentu berbeda dalam setiap orde pemerintahan, dan persaingan tersebut masih terus berlansung hingga sekarang dan mungkin sampai akhir zaman. Sungguhpun ketiga sistem hukum itu saling bersaing tetapi di antara ketiganya terdapat persinggungan, terutama hukum Islam yang mempunyai karakter inklusif dan akomodatif misalnya dengan doktrinnya bahwa adat/kebiasaan dapat dijadikan sumber hukum sepanjang adat/ kebiasaan tersebut tidak bertentangan dengan prinsip-prinsip ajaran Islam. ${ }^{31}$

\section{Prospek Hukum Islam di Indonesia}

Membaca prospek hukum Islam di Indonesia kita dapat menggunakan analisis SWOT dengan melihat secara obyektif kekuatan, kelemahan, peluang dan tantangan/ancaman hukum Islam.

${ }^{31}$ Lihat Jazuni, Legislasi Hukum Islam di Indonesia,PT.Citra Aditya Bakti, Bandung, 2005, 238 
Kekuatan hukum Islam di Indonesia antara lain berupa :

1. Dukungan umat Islam yang secara kuantitatif merupakan kelompok mayoritas dari aspek agama. Dukungan umat Islam tersebut akan mengelaborasi dalam bentuk kuatnya aspirasi hukum umat Islam dalam mempengaruhi proses legislasi secara signifikan. Dan aspirasi hukum mereka itu tentu haruslah direspon secara serius oleh parlemen atau pemerintah. Dalam era reformasi sekarang ini umat Islam sudah mulai merasa bebas menyuarakan aspirasinya untuk menuntut pemberlakuan hukum Islam, atau paling tidak, wacana-wacana hukum Islam sudah semakin sering mengemuka dalam tataran publik. Bagi umat Islam tidak ada pilihan selain meyakini bahwa mengamalkan hukum Islam dalam kehidupan keseharian mereka adalah berarti mengamalkan ajaran agama Islam itu sendiri secara total.

2. Hukum Islam secara substansial mempunyai karakter dinamis, elastis dan fleksibel yang didukung oleh prinsip-prinsip dan asasasas yang dimilikinya. Walaupun hukum Islam bersumber dari al-Qur'an dan al-Sunnah dan pertama kali diturunkan di Jazirah Arab tetapi karena Islam sebagai agama universal maka hukumhukum yang dikandungnya diyakini akan selalu relevan dan sesuai dengan kebutuhan umat manusia dimana saja berada di belahan bumi ini. Di dalam al-Qur'an dan al-Sunnah terdapat ketentuan-ketentuan yang sebagian berlaku tetap dan abadi dan sebagian yang lain dimungkinkan berubah dan dapat menyesuaikan dengan tuntutan tempat, zaman dan lingkungan yang kesemuanya dapat diketahui melalui aktivitas ijtihad. Dalam konteks Indonesia, sangat dimungkinkan didesain fiqh bercorak Indonesia.

3. Hukum Islam bersumber dari wahyu Allah yang Maha Mengetahui kebutuhan umat manusia. Karena itu ketentuan hukum Allah itu kita yakini sangat sempurna dan efektif serta lebih dapat menjamin keadilan yang dibutuhkan manusia dibanding hukum buatan manusia. Hukum Islam tidak hanya diproyeksikan untuk kehidupan di dunia saja tapi juga untuk kehidupan di akhirat kelak. Bukti empirik menunjukkan bahwa pemberlakuan hukum Islam (hukum pidana Islam) di Arab Saudi berjalan efektif dan dapat menekan angka kejahatan sampai pada titik yang sangat rendah. Freda Adler, seorang profesor dari negeri Paman Sam memasukkan negeri ini sebagai salah satu dari 
sepuluh negara dengan predikat negara negara terkecil angka kejahatannya dibanding negara-negara lain di dunia. Demikian juga hasil penelitian Souryal, seorang guru besar sistem peradilan pidana dari Sam Houston State University, Texas Amerika Serikat menunjukkan fakta empirik yang sama bahwa Arab Saudi merupakan negara yang terendah angka kejahatannya dibanding negara lain yang tidak menerapkan hukum Islam. ${ }^{32}$

Hukum Islam disamping mempunyai kekuatan sebagaimana tersebut di atas juga mempunyai kelemahan dalam arti nonsubstantif, antara lain meliputi :

1. Hukum Islam, sungguhpun didukung oleh umat Islam yang merupakan kelompok terbesar di negara kita tapi kebanyakan dari mereka masih tergolong awam terhadap hukum Islam. Sarjana-sarjana hukum di negara kita sungguhpun beragama Islam tidak banyak yang memahami substansi hukum Islam dan filsafatnya. Mereka lebih banyak mempelajari teori hukum Barat yang memiliki asas-asas dan prinsip-prinsip serta filosofi yang tentu berbeda, lebih-lebih di kebanyakan fakultas hukum umum mata kuliah hukum Islam diajarkan hanya sebagai pelengkap bukan mata kuliah pokok. Hal ini merupakan sebuah ironi dari kebesaran kuantitatif umat Islam di Indonesia

2. Hukum Islam di Indonesia tersebar dalam kitab-kitab klasik yang kebanyakan dikarang oleh ulama-ulama Timur Tengah. Dan tidak jarang rumusan-rumusannya masih merupakan perdebatanperdebatan atau madzhab-madzhab yang sangat variatif bahakan kontradiktif. Maka agar hukum Islam yang kondisinya seperti itu layak menjadi aturan perundang-undangan, diperlukan kerja keras dan serius dari para teoretisi hukum Islam untuk dapat menformulasikannya sedemikian rupa agar dapat dihasilkan kepastian hukum sesuai rasa keadilan rakyat Indonesia.

Adapun peluang bagi hukum Islam untuk dapat eksis di negara kita dapat digambarkan sebagai berikut :

1. Indonesia memiliki dasar negara Pancasila. Sila pertama Ketuhanan yang Maha Esa. Sila ini menjadi landasan fundamental bagi eksistensi agama Islam dan hukum-hukum yang menyertainya. Dari sila pertama ini selanjutnya

\footnotetext{
${ }^{32}$ Lihat Topo Santoso, Membumikan Hukum Pidana Islam, Gema Insani, Jakarta, 2003, 88-89
} 
diderivasikan Pasal 29 ayat (2) UUD 45, tentang agama dan Pasal 28A sampai dengan Pasal 28J UUD 45 tentang hak asasi manusia. Semua ketentuan ini menjamin pengamalan ajaran agama oleh setiap warga negara termasuk penerapan hukum agama dan bahwa hal tersebut merupakan hak asasi yang harus mendapat perlindungan dari negara.

2. Pemberlakuan otonomi daerah di Indonesia membuka ruang bagi penyaluran aspirasi hukum masyarakat di tingkat lokal secara bottom up sehingga dimungkinkan munculnya perda-perda yang bernuansa Islam sesuai kebutuhan masyarakat.

3. Pada perkembangan terakhir ini muncul dinamika di tengah masyarakat yang menunjukkan bahwa suatu yang berbasis syari'ah semakin marketable. Sebagai contoh, perbankan syari'ah, asuransi syari'ah, gadai syari'ah, MLM syari'ah, rumah sakit syari'ah, swalayan syari'ah dan lain lain, sehingga tidak heran apabila layanan syari'ah bermunculan di mana-mana dan bahkan dijadikan muatan iklan. Fenomena ini tentu memberi peluang baik bagi hukum Islam untuk dapat eksis dalam kehidupan masyarakat.

Di samping peluang sebagaimana tersebut di atas, hukum Islam juga dihadapkan kepada tantangan atau ancaman yang tidak ringan, antara lain:

1. Faham-faham atau ideologi-ideologi yang banyak mempengaruhi jalan pikiran sebagian masyarakat yang menekankan kebebasan dan pembelaan atas hak-hak asasi manusia (HAM) yang dasar filosofisnya bertentangan dengan ajaran agama. Tantangan atau ancaman ini akan terasa berat apabila berkenaan dengan pemberlakuan hukum pidana Islam yang selama ini distigmakan tidak humanis, barbarian, sadis dan kolot.

2. Kecemburuan dari kelompok non Islam yang kurang memahami sistem hukum Nasional dan posisi Islam dalam sistem kehidupan berbangsa dan bernegara, terutama mereka yang mengkhawatirkan timbulnya Islamisasi dalam semua aspek kehidupan dan bergesernya Indonesia dari negara Pancasila ke negara Islam yang akan membuat mereka menjadi kelompok marginal di bumi Indonesia ini. 


\section{Catatan Akhir}

Memperhatikan kekuatan dan peluang hukum Islam di Indonesia dengan membandingkannya terhadap kelemahan dan tantangan atau ancaman yang dihadapinya maka dapatlah ditarik sebuah kesimpulan bahwa hukum Islam mempunyai prospek yang memberikan harapan di Indonesia, sekalipun dengan sebuah catatan. Kesimpulan itu didukung oleh analisis sebagai berikut :

1. Kekuatan hukum Islam dan peluang yang dimilikinya di Indonesia sangat signifikan dalam menentukan prospek hukum Islam karena kekuatan dan peluang itu berbasis dukungan umat Islam yang secara kuantitatif mayoritas, dan landasan ideologiskonstitusional yang sangat fundamental.

2. Kelemahan dan tantangan/ancaman yang dihadapi hukum Islam di Indonesia hanyalah bersifat persepsional bukan fundamental. Persepsi masyarakat tentang hukum Islam akan selalu dinamis sejalan tingkat pengetahuan, kesadaran beragama dan perkembangan budaya bangsa.

Sungguhpun demikian, catatan yang perlu dikemukakan dalam konteks ini adalah bahwa apabila hukum Islam itu mengenai hukum pidana Islam maka pemberlakuannya di Indonesia masih membutuhkan perjuangan yang tidak ringan. Ada beberapa kendala yang menghadang antara lain :

a. Kendala kultural atau sosiologis, yaitu adanya sebagian umat Islam yang belum bisa menerima pemberlakuan hukum pidana Islam karena kesenjangan nilai-nilai kultural dan sosiologis yang terjadi di Indonesia.

b. Kendala ideologis, yaitu banyaknya pandangan negatif terhadap hukum pidana Islam dan meragukan efektivitas penerapannya.

c. Kendala filosofis, berupa tuduhan bahwa hukum pidana Islam tidak adil, bahkan kejam, ketinggalan zaman dan bertentangan dengan cita hukum Nasional.

d. Kendala yuridis, tercermin dari belum adanya ketentuan hukum pidana positif yang bersumber dari syariat Islam.

e. Kendala akademik, terlihat dari belum meluasnya kajian hukum pidana Islam di sekolah atau di perguruan tinggi

f. Kendala struktural yang terlihat dari belum adanya struktur hukum yang dapat mendukung penerapan hukum pidana Islam. 
g. Kendala referensi ilmiah, tercermin dari kurang banyaknya literatur ilmiah yang mengkaji hukum pidana Islam secara filosofis.

h. Kendala politis, terlihat dari belum memadainya kekuatan politik umat Islam untuk meloloskan pemberlakuan hukum pidana Islam melalui proses politik.

Kendala-kendala diatas menggambarkan betapa formalisasi hukum pidana Islam di Indonesia masih memerlukan perjuangan yang amat berat dan aksi nyata yang terprogram dan sistematik. 


\section{DAFTAR PUSTAKA}

Ali, Muhamad Daud. (1991). "Hukum Islam, Peradilan dan Masalahnya", dalam Hukum Islam di Indonesia , Pemikiran dan Praktik. Bandung: PT. Remaja Rosda Karya.

Arifin, Bustanul. (1995). Gagasan dan Sasaran Kompilasi Hukum Islam. Makalah. PTA Jawa Timur.

Fuad, Mahsun. 2005). Hukum Islam Indonesia. Yogyakarta: LKiS.

Haidar, Ali. (1994). Nabdatul Ulama dan Islam di Indonesia. Jakarta: PT. Gramedia Pustaka Utama.

Ichtijanto. (1991). "Pengembangan Teori Berlakunya Hukum Islam di Indonesia", dalam Tjun Suryaman (ed.), Hukum Islam di Indonesia: Perkembangan dan Pembentukan. Bandung: Rosda Karya.

-----------. (1996). "Prospek Peradilan Agama Sebagai Peradilan Negara dalam Sistem Politik Hukum di Indonesia”, dalam Amrullah Ahmad, Dimensi Hukum Islam dalam Sistem Hukum Nasional. Jakarta: Gema Insani Press.

Jazuni. (2005). Legislasi Hukum Islam di Indonesia. Bandung: PT.Citra Aditya Bakti.

Kamaruzzaman. (2001). Relasi Islam dan Negara. Magelang: Indonesia Tera.

Lukito, Ratno. (1998) Pergumulan Antara Hukum Islam dan Hukum Adat di Indonesia. Jakarta: INIS.

Manan, Abdul. (2006). Reformasi Hukum Islam di Indonesia. Jakarta: PT.RajaGrafindo Persada.

Masud, Muhammad Khalid, Pencarian Landasan Normatif Syariah Para Ahli Hukum Islam dalam Dinamika Kontemporer Dalam Masyarakat Islam, dihimpun oleh Dick van der Meij. (2003). terj. Soemardi. Jakarta: INIS.

MD, Moh.Mahfud. (1998). Politik Hukum di Indonesia,Cet.I. Jakarta: LP3ES.

Nasution, Yunan. (1988). Islam dan Problema-problema Kemasyarakatan. Jakarta: Bulan Bintang.

Nuruddin, Amiur dkk. (2004). Hukum Perdata Islam di Indonesia. Jakarta: Prenada Media. 
Rasyidi, Lili \& Rasyidi, Ira. (2001). Dasar dasar Filsafat dan Teori Hukum. Bandung: PT Citra Aditya Bakti.

Santoso, Topo. (2003). Membumikan Hukum Pidana Islam. Jakarta: Gema Insani.

Schacht, Joseph. (2003). an Introduction to Islamic Law, terj. Joko Supomo. Yogyakarta: Islamika.

Soekanto, Soerjono \& Abdullah, Mustafa. (1987). Sosiologi Hukum dalam Masyarakat. Jakarta: Rajawali.

Suryanegara, Ahmad Mansur. (1995). Menemukan Sejarah Wacana Pergerakan Islam di Indonesia. Bandung: Mizan.

Suseno, Franz Magnis. (2000). Kuasa dan Moral. Jakarta: Gramedia Pustaka Utama.

Syadzali, Munawir, "Peradilan Agama dan Kompilasi Hukum Islam", dalam Dadan Muttaqin (ed.). (1999). Peradilan Agama dan Kompilasi Hukum Islam dalam Tata Hukum Indonesia. Yogyakarta: UII Press.

Undang-Undang Nomor 14 Tahun 1970 selanjutnya diubah dengan Undang-Undang Nomor 35 Tahun 1999 tentang Perubahan atas Undang-Undang Nomor 14 Taun 1970 tentang Ketentuan Ketentuan Pokok Kekuasaan Kehakiman. Kemudian Undang-Undang ini diubah kembali dengan Undang-Undang Nomor 4 Tahun 2004 tentang Kekuasaan Kehakiman dan diubah lagi dengan UndangUndang Nomor 48 Tahun 2009 tentang Kekuasaan Kehakiman.

Undang-Undang. Nomor 7 Tahun 1989 selanjutnya diubah dengan Undang-Undang.Nomor.3 Tahun 2006 tentang Perubahan atas Undang-Undang.Nomor 7 Tahun 1989 tentang Peradilan Agama dan diubah lagi dengan Undang-Undang Nomor 50 Tahun 2009 tentang Peradilan Agama.

Kitab-kitab tersebut adalah: Al-Bajuri, Fath al Mu'in, Syarqowi 'ala alTabrir, Qalyubi/Mahalli, Fath al-Wabhab dengan Syarab-nya, Tubfah, Targhib al-Musytaq, Qawanin Syariyah li al-Sayyid Utsman ibn Yabya, Qawanin Syar'iyah li al-Sayyid Shadaqah Dablan, Syamsuri fi al-Faraidl, Bughyah al-Mustarsyidin, al-Figh Ala al Madzahib al-Arba'ah, Mughni al-Mubtaj. Lihat Kompilasi Hukum Islamdi Indonesia, Pengadilan Tinggi Agama Jawa Timur, 1995.

Kompilasi Hukum Islam di Indonesia. 